\title{
Dental Identification of a Mummified Body using Dental Cast and Prosthesis
}

\begin{abstract}
Keywords: Forensic odontology; Dental records; Dental models; Forensic anthropology; Dental prosthesis

Abstract

Forensic dentistry can significantly contribute to the identification of victims especially in cases of charred, decomposing, mutilated or skeletonized bodies. However, in order to make this procedure technically feasible it is necessary to find dental records produced before death. This study aims to report a case of a mummified body identified through dental traits found within a plaster cast, discussing the legal aspects contained in this procedure. A partially skeletonized body in advanced stage of decomposition, with mummified soft tissue was found. The dental autopsy revealed the presence of teeth with amalgam and composite fillings, and teeth missing ante-mortem (AM) and post-mortem (PM). Specifically, the teeth \# 16, \#17, \#26 and \#27 showed the presence of cavities compatible with niches for removable dental prosthesis. The relatives of the alleged victim provided the AM data, consisting of registers of clinical exam and an upper denta prosthesis embedded in a plaster cast. The outcomes from the AM/PM dental comparison revealed 15 converging points, 8 similarities, and 7 explainable discrepancies. In addition, the dental prosthesis provided within the plaster cast fit perfectly in the upper dental arch of the corpse, showing that the plaster dentition was casted from the victim. Therefore, it was possible to positively correlate the unidentified body with the potential missing person. The use of dental casts represents a useful tool in forensic odontology considering that these evidences allow a three-dimensional evaluation of the dental arches, revealing unique information for human identifications.
\end{abstract}

\section{Introduction}

With the increasing urban violence forensic services are receiving more cases of charred, decomposing, mutilated and skeletonized bodies [1-3]. In this context, the determination of the cause of death is difficult and normally the identification by means of fingerprints is not feasible, once the soft tissue may be deteriorated by environmental factors. Differently, bones, teeth and dental materials are often preserved [1,3-5].

Based on that, forensic dentistry significantly contributes to human identification, both in isolated cases or mass disasters. However, in order to reach a comparative dental identification antemortem (AM) data is necessary. The AM data consists of dental records normally composed by written documents, such as the registration of treatment plan and interventions, health care questionnaires, and clinical interviews; as well as by imaging documents, such as radiographs, photographs and dental casts [4,6-8].

Considering that the literature presents few cases of human identification using dental casts [9] and that these evidences are often produced in the routine of Dentistry, this study aims to report a case of a mummified body identified through dental traits found within a dental cast, discussing the legal aspects involved in this procedure.

\section{Journal of}

Forensic

Investigation

\section{Rhonan Ferreira Silva ${ }^{1,2 *}$, Mayara Barbosa Viandelli Mundim ${ }^{1}$, Fernando Fortes Picoli ${ }^{1,2}$ and Ademir Franco ${ }^{3}$}

${ }^{1}$ School of Dentistry, Federal University of Goias, Brazil

${ }^{2}$ Department of Forensic Medicine, Scientific Police, State of Goias, Brazil

${ }^{3}$ Forensic Dentistry, Katholieke Universiteit Leuven, Belgium

\section{*Address for Correspondence}

Rhonan Ferreira Silva, DDS, MSc, PhD, School of Dentistry, Federal University of Goias, Instituto Medico-Legal, Avenida Atilio Correa Lima 1223, Cidade Jardim, Goiania, Goias, Brazil, Zip Code 74425030, Tel/ Fax: + 5562 32011270; E-mail: rhonanfs@terra.com.br

Submission: 22 August, 2015

Accepted: 24 September, 2015

Published: 28 September, 2015

Copyright: () 2015 Silva RF, et al. This is an open access article distributed under the Creative Commons Attribution License, which permits unrestricted use, distribution, and reproduction in any medium, provided the original work is properly cited.

Reviewed \& Approved by: Dr. Vicki Wedel, Assistant Professor of Anatomy, Western University of Health Sciences, USA

\section{Case Report}

In 2014 a partially skeletonized body was found in advanced stage of decomposition, with mummified soft tissues. After the investigation of the potential crime scene, the body was referred to the local medico-legal institute in order to determine the cause of death cause and to proceed with human identification.

Radiographic exams revealed the presence of metallic fragments compatible with a firearm projectile in the skull. Bone fractures were also observed in the skull, in the left scapula and in six vertebrae (T4, T5, T4, T11, T12 and L1). The cause of death was registered as traumatic brain injury (Figure 1).

Anthropological exams detected the presence of male cranial and pelvic features; adult age; height between $1.64 \mathrm{~m}$ and $1.71 \mathrm{~m}$ [10]

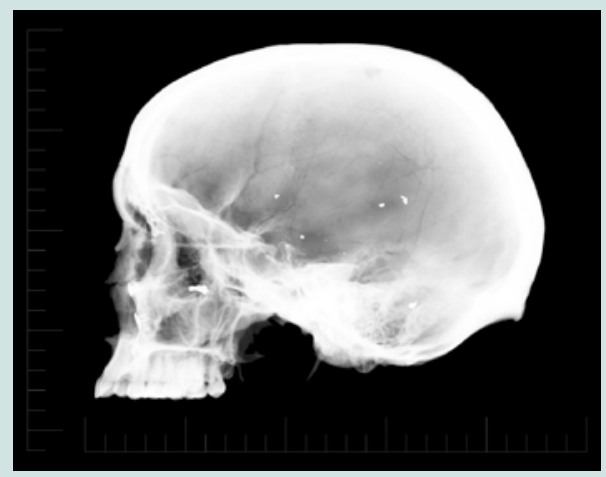

Figure 1: Skull radiograph showing the presence of metallic fragments compatible with fragments of firearm projectiles. 
Citation: Silva RF, Viandelli Mundim MB, Picoli FF, Franco A. Dental Identification of a Mummified Body using Dental Cast and Prosthesis. J Forensic Investigation. 2015;3(2): 3.

and indeterminate ancestry. The lambdoid and sagittal sutures had extensive areas of synostosis (Figure 2).

On the left side of the skull the presence of three metal plates fixed by screws was observed, indicating signs of previous treatment for bone fracture reduction.

Dental exams showed the presence of teeth with amalgam and composite fillings, as well as ante-mortem (AM) and post-mortem (PM) missing teeth (Figure 3 ). The remaining third molars were erupted. The teeth \#16, \#17, \#26 and \#27 revealed cavity preparations compatible with niches for removable partial dental prosthesis.

The relatives of the alleged victim were found during the investigation, and asked to provide dental records. The AM data produced in 2014, consisted of registers of clinical exam and an upper dental prosthesis within a dental cast (Figure 3). The missing person was a 25 -year-old male, disappeared for approximately 100 days.
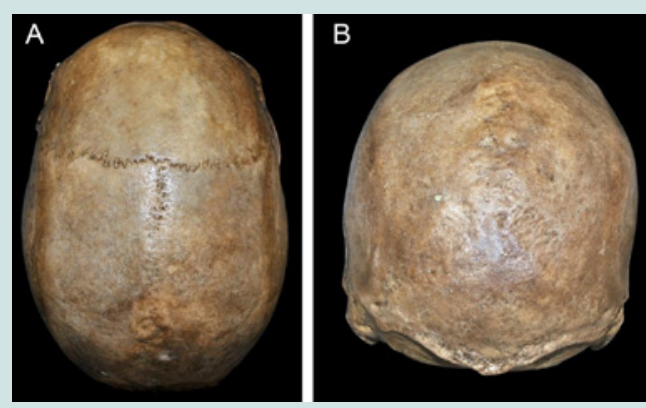

Figure 2: Superior $(A)$ and posterior $(B)$ views of the skull exhibiting the levels of synostosis in sagittal and lambdoid sutures.

Table 1: Comparison between the dental particularities evidenced in the antemortem (AM) records (plaster cast) and in the post-mortem (PM) records (corpse maxillary dental arch)

\begin{tabular}{|c|c|c|c|}
\hline Tooth* & AM & PM & Outcome \\
\hline 11 & Old loss & Old loss & SI \\
\hline 12 & Old loss & Old loss & $\mathrm{SI}$ \\
\hline 13 & Intact tooth & Intact tooth & $\mathrm{SI}$ \\
\hline 14 & $\begin{array}{l}\text { Old loss, without } \\
\text { remaining space }\end{array}$ & $\begin{array}{c}\text { Old loss, without remaining } \\
\text { space }\end{array}$ & SI \\
\hline 15 & Occlusal amalgam filling & ${ }^{* *}$ Occlusal filling & ED \\
\hline 16 & $\begin{array}{l}\text { Occlusal composite } \\
\text { filling + distal niche }\end{array}$ & $\begin{array}{l}{ }^{* *} \text { Occlusal filling + distal } \\
\text { niche }\end{array}$ & ED \\
\hline 17 & $\begin{array}{l}\text { Occlusal composite } \\
\text { filling + mesial niche }\end{array}$ & $\begin{array}{l}{ }^{* *} \text { Occlusal filling }+ \text { mesial } \\
\text { niche }\end{array}$ & ED \\
\hline 18 & Intact tooth & Intact tooth & $\mathrm{SI}$ \\
\hline 21 & Intact tooth & Intact tooth & $\mathrm{SI}$ \\
\hline 22 & Intact tooth & PM loss & ED \\
\hline 23 & Intact tooth & Intact tooth & $\mathrm{SI}$ \\
\hline 24 & $\begin{array}{l}\text { Intact tooth, twisted } \\
\text { tooth }\end{array}$ & Intact tooth, twisted tooth & SI \\
\hline 25 & Occlusal amalgam filling & ${ }^{* *}$ Occlusal filling & ED \\
\hline 26 & $\begin{array}{c}\text { Occlusal amalgam filling } \\
+ \text { distal niche }\end{array}$ & $\begin{array}{l}{ }^{* *} \text { Occlusal filling + distal } \\
\text { niche }\end{array}$ & ED \\
\hline 27 & $\begin{array}{l}\text { Occlusal amalgam filling } \\
+ \text { mesial niche }\end{array}$ & $\begin{array}{l}{ }^{* *} \text { Occlusal filling }+ \text { mesial } \\
\text { niche }\end{array}$ & ED \\
\hline 28 & Intact tooth & Intact tooth & SI \\
\hline
\end{tabular}

SI: Similarity; ED: Explainable Discrepancy

*Dental notation recommended by FDI.

${ }^{* *}$ Restorative material could not be identified.
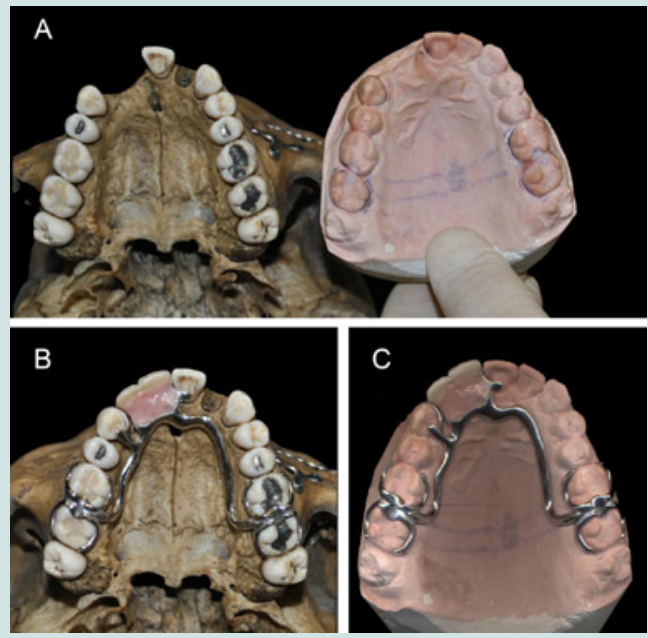

Figure 3: Occlusal view of the comparisons between the PM upper dental arch and the dental cast without the prosthesis (A); dental prosthesis fit in the PM upper dental arch (B) and on the dental cast (C).

Additionally, the probable victim had a history of facial trauma and left the dental treatment before receiving the dental prosthesis.

The comparison between the evidences found within the dental cast (AM) and the evidences detected during the dental autopsy (PM) was performed revealing 15 converging points, 8 similarities, and 7 explainable discrepancies (Table 1). In addition, the partial dental prosthesis provided within the dental cast fit perfectly in the upper dental arch of the body, showing that the dentition was casted from the missing person (Figure 3). Therefore, the AM and PM evidences were positively correlated indicating that the body belonged to the missing person.

\section{Discussion}

Dental identification has great relevance for human identifications, being the first method of choice when the fingerprint examination cannot be performed, as in cases of charred or decomposed bodies. The dental analysis consists of a comparative method and depends on records produced before death (AM) that can be compared with the postmortem (PM) dental findings present in the dental arches unknown bodies [11].

Normally, the AM dental records may consist of oral and clinical registers [12], dental radiographs [6], photographs $[3,8]$ and dental casts [9], which are generally produced for orthodontic or prosthetic purposes.

In Brazil, there is an ethical orientation in the sense that all dental records must be maintained indefinitely [13], in order to aid solving legal questions concerning the quality of the dental treatments, as well as to assist in cases of human identification. The case reported has a peculiarity regarding the short time gap between the time of production of the AM and the PM record examination (less than 4 months) since the missing person was under prosthetic treatment and disappeared before it was concluded.

Apart from the necessity to store dental records, there is also a concern about the physical space that must be intended for archiving dental records, especially the dental casts, which usually require 
Citation: Silva RF, Viandelli Mundim MB, Picoli FF, Franco A. Dental Identification of a Mummified Body using Dental Cast and Prosthesis. J Forensic Investigation. 2015;3(2): 3.

larger space than photographs and radiographs [9]. An option for the required space is the digitalization, recently performed by intraoral $[14,15]$ and laser scans. However, it does not replace the production of dental casts for making dental prosthesis, especially the removable partial type.

In relation to the potential information present in the dental casts, the greater advantage it is observed on the three-dimensional visualization and manipulation, which can be useful to investigate the dimensions, shapes, and positioning of the crowns disposed in the dental arch, increasing the possibility of uniqueness in the analyzed dentition. Additionally to the analysis of dental traits in the dental casts, a procedure already reported in the literature [9] was also performed in the present study, consisting of the verification of prosthetic adaptation of the partial denture in the upper dental arch of the body. Thus, another positive parameter for dental identification was achieved.

Finally, the present case also revealed an inconsistent anthropological finding with the analysis of lambdoid and sagittal cranial sutures, which suggested a much older age than the chronological age of the victim. In these situations, the search for more bone and dental age information is indicated and caution is advised in order to avoid mistaken conclusions [12].

\section{Conclusion}

The use of dental casts represents a useful tool in forensic odontology considering that these evidences allow a threedimensional evaluation of the dental arches, revealing unique information for human identifications.

\section{References}

1. Matoso RI, Benedicto Ede N, de Lima SH, Prado FB, Daruge E, et al. (2013) Positive identification of a burned body using an implanted orthopedic plate. Forensic Sci Int 229: 168.e1-e5

2. Silva RF, Franco A, Mendes SD, Picoli FF, de Azevedo Marinho DE (2014) Human identification through the patella--Report of two cases. Forensic Sci Int 238: e11-e14.
3. Silva RF, Franco A, Souza JB, Picoli FF, Mendes SD, et al. (2015) Human identification through the analysis of smile photographs. Am J Forensic Med Pathol 36: 71-74.

4. Obafunwa JO, Ogunbanjo VO, Ogunbanjo OB, Soyemi SS, Faduyile FA (2015) Forensic odontological observations in the victims of DANA air crash. Pan Afr Med J 20: 96.

5. Pol CA, Ghige SK, Gosavi SR, Hazarey VK (2015) Effects of elevated temperatures on different restorative materials: An aid to forensic identification processes. J Forensic Dent Sci 7: 148-152.

6. Manigandan T, Sumathy C, Elumalai M, Sathasivasubramanian S, Kannan A (2015) Forensic radiology in dentistry. J Pharm Bioallied Sci 7(Suppl 1): S260-S264.

7. Silva RF, Botelho TL, Prado FB, Kawagushi JT, Daruge Junior E, et al. (2011) Human identification based on cranial computed tomography scan: a case report. Dentomaxillofac Radiol 40: 257-261.

8. Silva RF, Pereira SD, Prado FB, Daruge E 2nd, Daruge E (2008) Forensic odontology identification using smile photograph analysis--case reports. J Forensic Odontostomatol 26: 12-17.

9. Silva RF, Ramos DI, Pereira SD, Daruge E, Daruge Junior E (2007) Mode cast: expertise relevance and forensic orientation for filing away. Rev Assoc Paul Cir Dent 61: 381-384.

10. Dupertuis CW, Hadden JA Jr (1951) On the reconstruction of stature from long bones. Am J Phys Anthropol 9: 15-53.

11. Rothwell BR (2001) Principles of dental identification. Dent Clin North Am 45: 253-270.

12. Silva RF, Dias PE, Picoli FF, Rodrigues LG, Mundim MB, et al. (2015) Anthropological discrepancies detected in putrefied body identified with dental records - a case report. Rev Bras Odontol Legal 2: 125-136.

13. Paranhos RL, de Magalhaes MP, Francio J, Terada HH, Rosario HD, et al. (2013) Time of guard of orthodontic records versus legal time for their prescription. Dental Press J Orthod 18: 113-117.

14. Londono J, Abreu A, Baker PS, Furness AR (2015) Fabrication of a definitive obturator from a $3 D$ cast with a chairside digital scanner for a patient with severe gag reflex: A clinical report. J Prosthet Dent [Epub ahead of print].

15. Polido WD (2010) Moldagens digitais e manuseio de modelos digitais: o futuro da Odontologia. Dental Press J Orthod 15: 18-22. 